\title{
Analysis of the Economic Impacts of Immigration in the United States
}

\author{
Michael Mclntosh, Economics and Political Science*
}

\begin{abstract}
In this paper, I attempt to establish a causal relationship between immigration and local economic outputs. My estimation sample consists of national data on each of educational attainment, wages, and native employment, organized by state. The sample also contains state- and national-level data on other macroeconomic factors including population, unemployment, Consumer Price Index, and a construction of remittances, that I believe impact the economic outputs. Estimation reveals positive effects of immigration on educational attainment and wages, and an ambiguous effect of immigration on native employment. I then discuss potential theoretical economic explanations for my estimation results, ranging from simple uncorrected endogeneity to labor supply and demand interactions, and a complementarity effect leading to labor specialization among immigrants. In sum, my data shows immigration having positive or neutral impacts on each of the economic outputs listed above. In many cases, I find these impacts can be explained by conventional economic theory rather than issues with the data or estimation methodology used.
\end{abstract}

\section{INTRODUCTION}

As the subject of global political interest for centuries, worldwide immigration has been on an upward trend in recent history. Mark Leonard (2016) claims that worldwide international migration is currently the highest it has been since World War II. Political unrest, widespread poverty, war, and scarcity of necessary resources increasingly force refugees from the Global South and the Third World, while relative economic stability, higher standards of living, and better job prospects in the West draw these migrants in (Leonard 2016). The recent influx of immigrants has appropriately pushed immigration to the center of many political debates, particularly in those countries that tend to serve as migrant destinations, including much of the developed world.

In the United States, immigration has steadily increased over time. Figure 1 depicts the rapid growth in immigration witnessed by the U.S. in the recent decades, while Figures 2.1 and 2.2 illustrate the changes in the distribution of immigrants across U.S. states. The growing presence of immigrants in local markets has generated questions

* Michael is a senior at the University of Oregon. Originally from Portland, Oregon, Michael will graduate in June with Bachelor of Science degrees in Economics and Political Science. Michael hopes to attend graduate school in the Fall, pursuing a Master's in Public Policy, focusing on urban and social issues. In his free time, Michael likes to play basketball, volunteer, and watch videos of manatees. Please direct correspondence to: mmcintos@uoregon.edu. 
about their contribution and overall economic impact, specifically immigrants' effects on the welfare of native citizens. The economic effects of immigration in native labor markets are often cited in policy debates, both by pro- and anti-immigration camps. However, the direct effects of immigration on wages are not well known, and findings in the field are often ambiguous, particularly in their implications at the national level. An empiricallytested, causal understanding of the large-scale economic effects of immigration can inform these debates and suggest economically viable immigration policy options moving forward.

Several studies have emerged over the last two decades that attempt to establish this causal relationship between international migration and fluctuations in economic outputs in the home country. The results of these studies frequently conflict with one another. Borjas (2003) found that the effect of immigration on the earnings of native American workers is negative and significant-an outcome caused by the flooding of the U.S. labor market with low-skill immigrant workers. Peri (2012), on the other hand, found immigration to have a positive effect on native earnings, a conclusion extrapolated from the increased factor productivity experienced by native workers as a result of said immigration. Dozens of additional articles in the field similarly clash with one another in their results. These clashes can commonly be attributed to errors on both sides of the debate in data collection, such as sampling narrow geographic regions, failing to control for spatial correlations between immigrant proportion of the local labor force and local wages (Longhi et al. 2005), as well as model specification failures (Borjas 2013, Longhi et al. 2005).

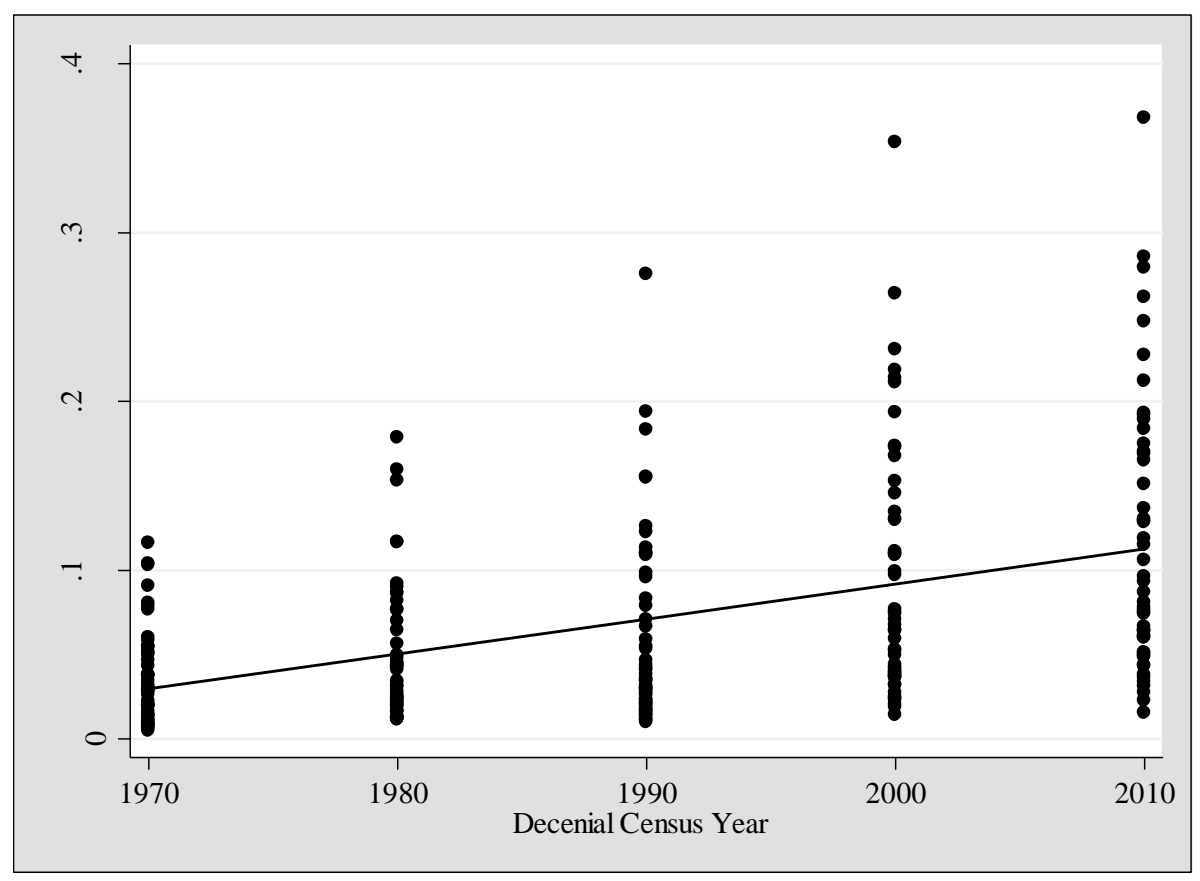

Figure 1: Growth in Immigrant Share Over Time 


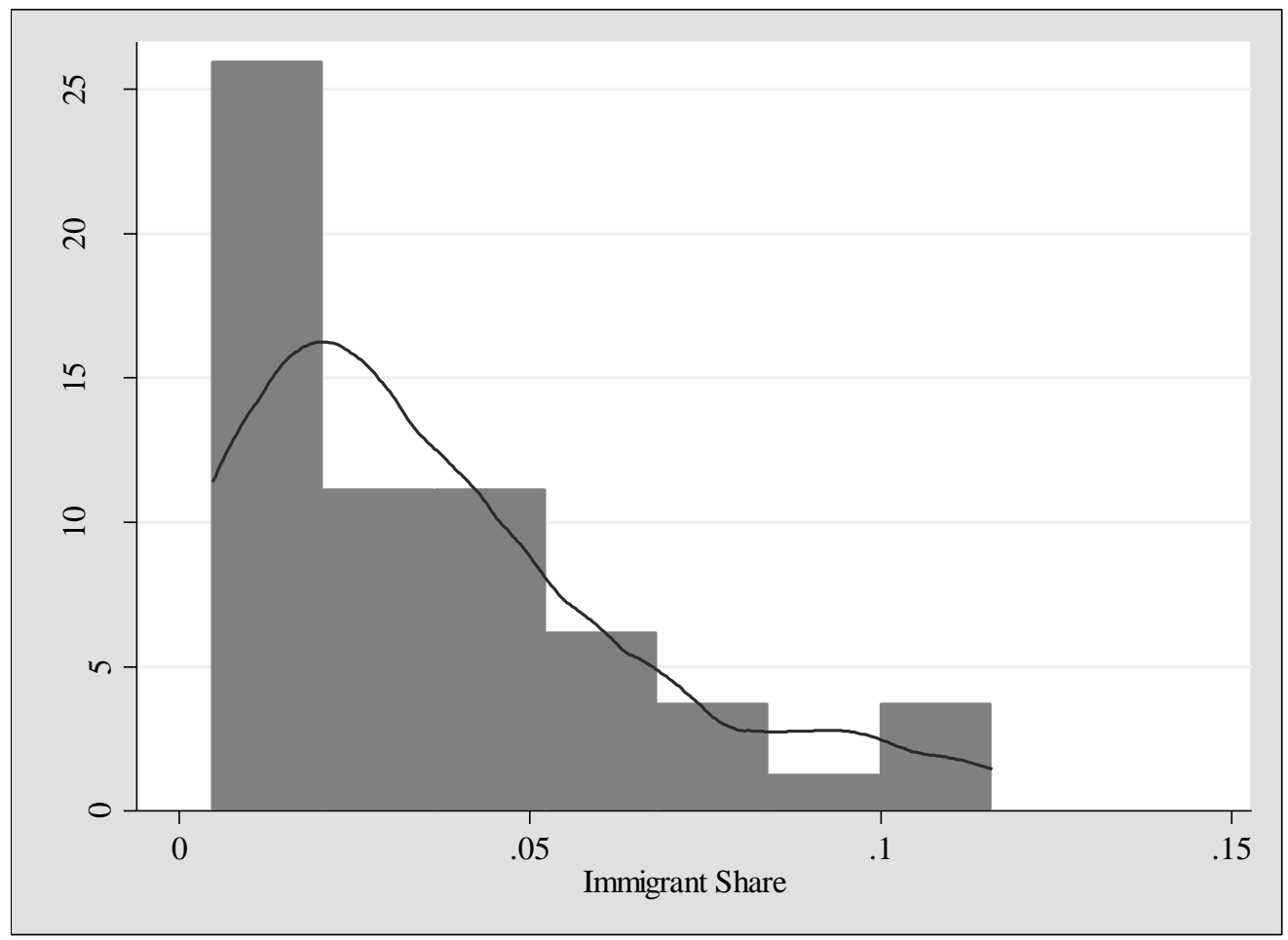

Figure 2.1: Immigrant Distribution, 1970

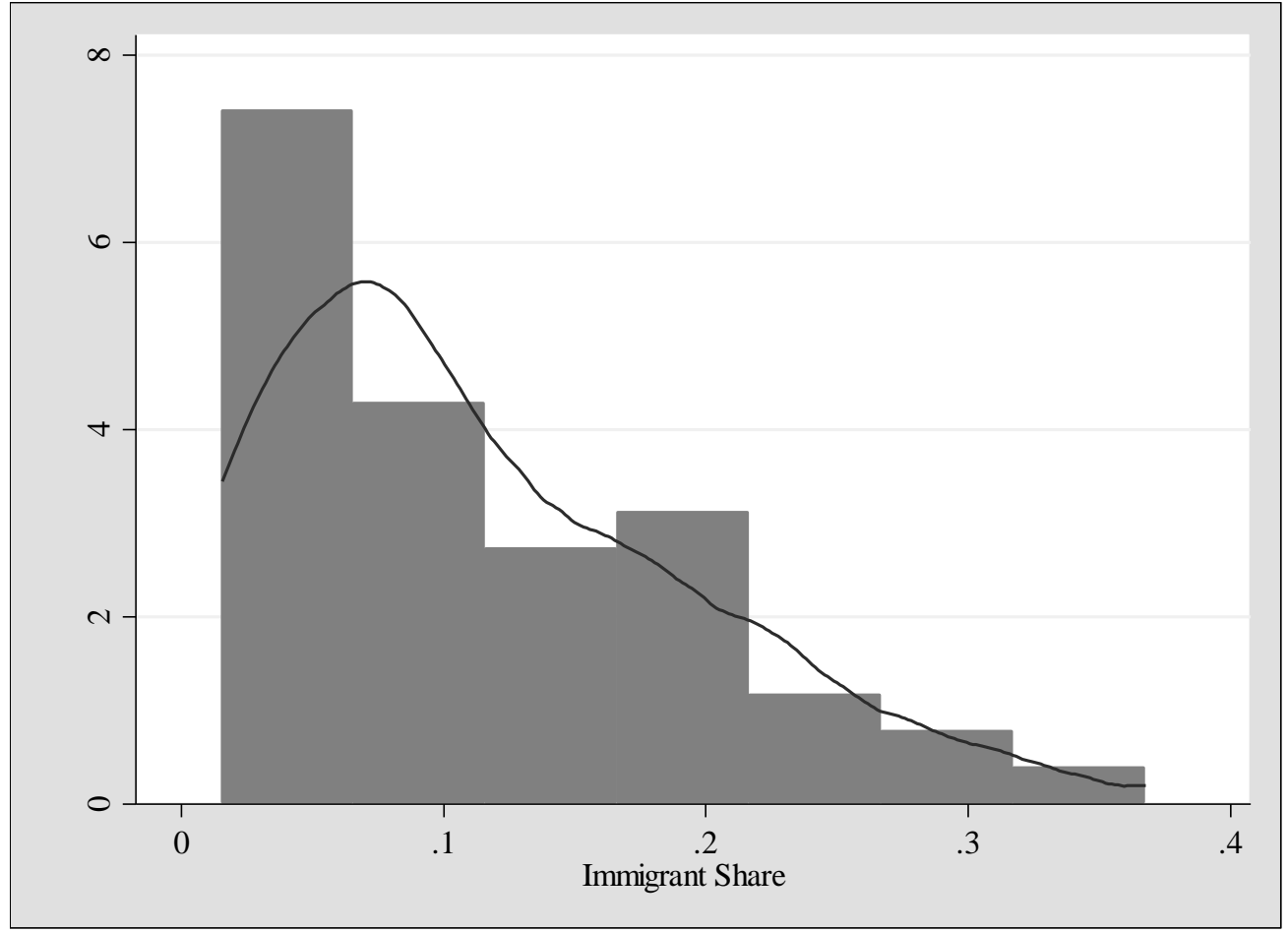

Figure 2.2: Immigrant Distribution, 2010 
This paper uses data from the United States broken down by state and year to overcome the biases that accompany more restrictive data sets. Through the analysis of the 50 U.S. states and the District of Columbia, observed over a period of 50 years, I attempt to generate a robust explanation as to immigration's impacts on various labor market outcomes. I focus on immigration's implications for native wages, native employment opportunities, and educational attainment. My analysis finds positive and significant impacts of immigration on wages, even in my most restrictive regressions. I also find variable impacts of immigrants on native employment opportunities, and finally a positive and significant effect on educational attainment. In analyzing my results, I discuss in depth plausible explanations for causality between immigration and these variables.

This study provides fresh insights into the effects of immigration in multiple ways. By drawing from the entire United States, I aim to correct one of the common data collection errors cited by Longhi et al. (2005) - narrow geographic sampling. Additionally I include several population measures in my model, including information on native and immigrant populations by skill level to likewise address the issue of spatial correlation put forth by Longhi et al. (2005). My large sample period allows us to observe several of the long-run implications that are not discernible in much of the related literature; many similar studies are restricted to ten- or fifteen-year sample periods that fail to capture tendencies of immigration over time.

The organization of the remainder of this paper is as follows: Section 2 provides a discussion of the economics of immigration drawn from the relevant literature, highlighting results from several studies closely related to ours. Section 3 presents my regression model and describes the methodology I follow in estimating the proposed model. Section 4 outlines the data sources and the data collection process, including any variable generation techniques. In Section 5 , I discuss the results of my model estimation. Finally, in Section 6 I discuss the conclusions drawn from my model estimation.

\section{LITERATURE REVIEW}

While the impacts of immigration have likely been studied for as long as international migration has occurred, interest in the field in the United States grew markedly after the 1965 Amendments to the Immigration and Nationality Act, which abolished immigration quotas established in 1921 (Borjas and Tienda 1987). However, as Simon (1989) pointed out, even after the amendments, much of the study was limited to discovering the public effects of immigrants, usually striving to determine the impact immigrants have on government spending and use of public goods. Very little thought was given to the impact immigrants would have on native citizens' private lives including personal income, employment, and education. In 1987, George Borjas and Marta Tienda published one of the first papers to analyze the impact of immigration on native wages. Since then, there has been a contentious debate surrounding immigration's ground level impacts with economic theory and empirical evidence supporting the arguments of both sides. 
Analysis of the economics of immigration is often constrained by inadequate knowledge of economic theory. A common misconception around immigration economics is the belief that "for every immigrant who finds employment, a native-born worker is displaced" (Borjas and Tienda 1987, p. 646). This argument fails to account for the flexibility of the labor market. Rather than having a fixed number of jobs that can be filled by immigrants and native workers alike, the labor market tends to expand and contract in response to the quantity and quality of labor available. The economic theory here supports the conclusion that as immigrants enter the market, the labor supply increases, which does result in an intersection with the labor demand curve at a lower equilibrium wage level, but does not contribute to the 1:1 job displacement cited above.

Furthermore, the variance in skill level across both native and immigrant workers also contributes to the effect immigrants have on native wages. For example, an influx of lowskilled workers will complement existing high-skill workers. The ability of these high-skill workers to specialize increases their productivity, directly increasing their wages (Peri 2012). This increased-productivity hypothesis is supported by a negligible effect of immigration on native share of employment (Ottaviano et al. 2013). These two studies found that, rather than displace native workers, immigrants gravitate toward low-skill jobs, encouraging native workers to transition into high-skill work while generating a complementarity effect that gives all workers a wage boost.

To exemplify a complementarity effect, picture a construction site in Cottage Grove staffed by contractors from Johnson Construction Co. Assume that all of Johnson's contractors are native workers. Now imagine an influx of immigrants to Cottage Grove. The new immigrants will be looking for jobs, and may be proficient in construction (traditionally low-skill labor). Meanwhile, the native contractors know the inner workings of Johnson, they have relationships with management at the company, and know how things work. For this example they represent high-skill labor. In this scenario, all of the workers can specialize to increase productivity. Native workers can capitalize on their knowledge of company operations to transition into supervisory or local management roles that they have a comparative advantage in, while immigrants can take the construction jobs, their particular area of comparative advantage. The two skill sets, and the two roles they lead to, complement one another and lead to increased overall productivity at the construction site.

Complementarity happens in contrast to the typical understanding of immigrant transition into the workforce, known as substitution. Were we to apply substitution to the example above, the immigrants arriving in Cottage Grove would compete with native workers for a fixed number of construction jobs, resulting in the 1:1 displacement discussed earlier. Substitution defies economic theory. A complete substitution effect is viable only under a precise set of assumptions, namely entirely inelastic labor demand, that are so unlikely in the real world so as to be irrelevant to this discussion. 
Both Ottaviano's and Peri's findings that immigrants tend to low-skill jobs provides compelling evidence that the immigrants themselves are low-skilled. While it is possible that immigrants become underemployed upon their arrival due to circumstances beyond their control, the idea that many U.S. immigrant workers are low-skilled resonates with Borjas' theory of negative selection. Borjas hypothesized that the skill demographics of migrants are dependent on the wage distribution in their home country. Many developing countries have high returns to skill, incentivizing skilled workers to remain employed there. These returns stem from simple scarcity: when a lower percentage of the workforce is skilled, skilled workers earn higher wages. The implication then is that those that migrate from developing countries do so because they did not have the skills to be economically prosperous at home (Borjas 1989). This theory has been challenged by Chiquiar and Hanson (2005) using evidence from Mexican immigration to show that Mexican immigrants tend to be better educated than Mexican residents. The finding that immigrants take low-skill jobs remains valid, though the question of their job selection resulting from their own lack of skills or some other factor remains to be answered.

As stated above, empirical results surrounding immigration's impact on economic outputs vary depending on the study and the data used. Borjas (2013) used a model with homogeneous labor and asserts that there will be a permanent wage reduction when immigration expands the workforce faster than it expands the consumer base. As consumer demand will increase slower than labor supply, at the very least a small negative impact on wages occurs. Borjas' findings are corroborated by Ciccone and Peri (2005) who found a significant negative wage elasticity with regards to immigration. In contrast to the pessimistic wage predictions, Peri (2012) later reported "no evidence of crowding out of native employment by immigrants". He attributes any positive effects to an increase in worker productivity, which is identified from a model that controls for worker skill. In other words, Peri held worker skill constant across natives and immigrants and finds that employment is consistently awarded on the basis of worker productivity rather than national origin. Lewis (2005) found no effect of immigrants on native wages because of a labor market adaptation to the skill levels of its workers, using a model that controls for firm choices in technology investments.

From this discussion, it becomes clear that the results from the various models range across the board. In this study, I develop a model that includes many of the factors mentioned above while also accounting for several new variables that economic theory predicts will be relevant. More specifically, I control for the skill level of immigrants, for location-specific characteristics, and for other relevant economic variables described in more detail in the next section.

\section{CONCEPTUAL MODEL AND ESTIMATION METHODOLOGY}

As seen above, there are several competing narratives explaining the economic impacts of immigration. In many such explanations, immigration is only a fraction of 
the overall story, with other factors affecting a specific economic outcome. Keeping this in mind, I propose the following econometric model:

$$
y_{s t}=\beta_{o}+\beta_{1} \text { time }_{t}+\beta_{2} \text { location }_{s t}+\beta_{3} \text { immigration }_{s t}+\varepsilon_{s t}
$$

where $\mathbf{y}$ represents an economic outcome of interest (e.g. educational attainment, wages, or native employment level), time is a collection of temporal variables meant to control for macroeconomic factors or shocks, and location consists of a group of state-specific variables. I isolate immigration, as it is the variable of interest. The subscripts $s$ and $t$ indicate the state and time level of variation in the data sample.

Estimation of the regression model in equation (1) produces $\boldsymbol{\beta}$ coefficients. The estimate $\boldsymbol{\beta}_{\mathbf{3}}$ is our coefficient of interest as it measures the impact that changes in immigration levels have on the outcome variable, $\mathbf{y}$. Discussion of my estimation results focuses primarily on the sign, magnitude, and significance of the $\boldsymbol{\beta}_{\mathbf{3}}$ estimate.

I estimate my model using a sequence of five increasingly restrictive Ordinary Least Squares (OLS) regressions. To begin, I run the most basic regression of economic output, $\mathbf{y}$, on immigration. I then add to my regression model variables that capture macroeconomic effects: the process begins with the addition of labor shocks, then income and economic shocks, and then state-specific characteristics. In the final and most restrictive regression, year dummies and location fixed effects are included to control for unobservable factors that may affect the economic output $\mathbf{y}$.

One of the key assumptions of the OLS methodology is that the explanatory variables from the model in equation (1) are uncorrelated with the regression residual. When this assumption is satisfied, the estimated $\boldsymbol{\beta}$ coefficients are unbiased. In our case, it is possible that this assumption does not hold. I believe there is a potential for endogeneity amongst several of the variables in my model. Endogeneity, sometimes called simultaneous causality, occurs when two variables correlate strongly without any indication of the causal direction: which variable is the cause, and which is the effect? I can come up with reasonable explanations as to how the values of particular economic variables will drive immigrant settlement patterns which can help address the endogeneity issue, but is not a certain fix. I will examine specific areas where I suspect endogeneity may bias my estimates during discussion of the results of my estimation. In the case of endogeneity, it is difficult to determine causality between the two variables: does a larger immigrant population cause change in an economic output, or do varied levels of the output draw larger immigrant populations?

The econometric solution to the issue of endogeneity is to use instrumental variables, which in turn calls for the use of Two Stage Least Squares (2SLS) estimation methodology. Without becoming too tangential, 2SLS is an econometric methodology that makes use of an instrumental variable to correct for endogeneity. In the case of wages and employment, 
I run 2SLS specifications of equation (1) in addition to simple OLS to correct for potential endogeneity. I elaborate more on this in the results section.

\section{DATA AND SAMPLE CONSTRUCTION}

The data set in this paper draws from three main sources: U.S. Decennial Census data, St. Louis Federal Reserve (FRED) economic data, and a data set developed by Gaetano Basso and Giovanni Peri (2015). Much of my sample is taken from the decennial years covering the period 1970-2010. The only exception to this time interval is my chosen instrument used in the 2SLS estimation, which consists of a 20-year lagged immigration measure. ${ }^{1}$ The U.S. Decennial Census data used in this study spans the period 1950-2010, (with 1950 and 1960 data providing my lagged observations) and provides us with data on educational attainment (given as the share of population holding a bachelor's degree or higher at the time of survey), and total population by state and year.

The St. Louis FRED provides data on a number of economic indicators. First, the Census data being decennial, I used the FRED data to construct a variable to measure the number of months during which the United States' economy was in recession in each tenyear cycle. I express this number as a share of the total 120 months available between each decennial observation. I also use seasonally adjusted unemployment data by state and year, the average housing transaction price by state and year, and the Consumer Price Index (CPI) by year. The housing price and the CPI are indexed by the year 1980 to normalize observations. Additionally, with housing price and CPI only available from 1975-2010, 1970 observations for these variables have been linearly extrapolated from the existing data.

The remaining economic variables are found in the Basso and Peri (2015) data set. This data set is constructed using a combination of U.S. Decennial Census data and the American Community Survey data. It includes data on employment and wages, population level, immigrant level, and immigrant share by state and year. All population data provided by the Basso-Peri data set is limited to individuals ages 18-64, a remnant of data constraints specific to the Basso-Peri study. Employment data is measured in four ways: number of working age native individuals employed, share of working age native individuals employed, number of high-skill individuals employed, and number of lowskill individuals employed. Wage data is provided as the log of the average annual wage in each state, overall and for high- and low-skill individuals. Population was provided as the number of working age individuals in a particular state, but I have applied a natural $\log$ function to it to normalize my observations. Similar data is provided on both the number of immigrants in a particular state, and the share of a particular state's working age population that is non-native.

To control for particular geographic effects, I created dummy location variables. I divided the continental United States into 4 "Latitude Zones" with the northernmost states comprising Latitude Zone 1, and working down to the southernmost states making 
up Latitude Zone 4. The non-continental states, Alaska and Hawaii, have been omitted. A complete list of states by Latitude Zone is presented below.

Table 1: Latitude Zone Construction

\begin{tabular}{|c|c|c|c|}
\hline \multicolumn{4}{|c|}{ Latitude Zone } \\
\hline 1 & 2 & 3 & 4 \\
\hline $\begin{array}{l}\text { Maine, } \\
\text { Minnesota, } \\
\text { Montana, } \\
\text { North } \\
\text { Dakota, } \\
\text { Washington }\end{array}$ & $\begin{array}{l}\text { Connecticut, Idaho, Iowa, } \\
\text { Massachusetts, Michigan, } \\
\text { Nebraska, New Hampshire, } \\
\text { New Jersey, New York, Ohio, } \\
\text { Oregon, Pennsylvania, Rhode } \\
\text { Island, South Dakota, Vermont, } \\
\text { Wisconsin, Wyoming }\end{array}$ & $\begin{array}{l}\text { Arkansas, California, } \\
\text { Colorado, Delaware, District } \\
\text { of Columbia, Illinois, Indiana, } \\
\text { Kansas, Kentucky, Maryland, } \\
\text { Missouri, Nevada, North } \\
\text { Carolina, Oklahoma, } \\
\text { Tennessee, Utah, Virginia, } \\
\text { West Virginia }\end{array}$ & $\begin{array}{l}\text { Alabama, Arizona, } \\
\text { Florida, Georgia, } \\
\text { Louisiana, } \\
\text { Mississippi, New } \\
\text { Mexico, South } \\
\text { Carolina, Texas }\end{array}$ \\
\hline
\end{tabular}

Finally, I constructed a measure of state-level remittances. This variable is intended to capture the hypothesis postulated by George Borjas (2013). Borjas contended that the negative effects of immigration on employment and wages are exacerbated by immigrants' intention to send money to family or friends remaining in their country of origin. By including remittances, I hope to capture this effect in a novel fashion. Total U.S. remittances data by year is extant, however data on remittances by state-year have proven elusive. To accommodate, I construct a crude measure of state-year remittances by taking each state's share of total U.S. immigrant population in a particular observation year and multiplying it by U.S. remittances for the year as shown below:

Immigrant Pop $_{\text {state, year/Immigrant Pop }}$ United States, year=Immigrant Share state, year

Immigrant Share $_{\text {state, year }}{ }^{*}$ Remittances United States, year $=$ Remittances $_{\text {state, year }}$

While this data imputation method includes several problematic assumptions, namely, it presumes that each immigrant is equally as likely to pay remittances as the next, it does provide some measure of the relative sizes of remittances, enabling me to test Borjas' hypothesis. The summary statistics for each variable in my data set are presented below. 
Table 2: Summary Statistics

\begin{tabular}{lccccc}
\hline Variable & Observations & Mean & Std. & Min & Max \\
\hline $\ln$ (Annual Wage) & 255 & 10.11876 & 0.137436 & 9.819204 & 10.51251 \\
$\ln ($ Low Skill Annual Wage) & 255 & 9.895525 & 0.13331 & 9.629357 & 10.28744 \\
$\ln$ (High Skill Annual Wage) & 255 & 10.25794 & 0.135232 & 9.922424 & 10.61805 \\
$\ln$ (Population) & 255 & 14.22985 & 1.060512 & 11.83356 & 16.82147 \\
Immigrant Share & 255 & 0.071067 & 0.06629 & 0.004712 & 0.367678 \\
Immigrant Population & 255 & 301060 & 803884.3 & 2200 & 7429145 \\
Native Population & 255 & 2263535 & 2285547 & 132600 & $1.28 \mathrm{E}+07$ \\
Native Employment & 255 & 1849596 & 1866898 & 104500 & $1.03 \mathrm{E}+07$ \\
Education Level & 255 & 0.212059 & 0.090634 & 0.068 & 0.773 \\
Recession Months & 255 & 0.155 & 0.063721 & 0.066667 & 0.216667 \\
State Unemployment & 255 & 0.060729 & 0.023875 & 0.01 & 0.137 \\
Housing Transaction Price & 255 & 1.713883 & 1.179531 & -1.1433 & 6.1553 \\
Consumer Price Index & 255 & 1.5588 & 0.771275 & 0.471 & 2.647 \\
ln(State Remittances) & 255 & 17.05482 & 2.393115 & 11.90941 & 22.96728 \\
\hline
\end{tabular}

\section{RESULTS}

It is easy to come up with stories for both positive and negative effects of immigration on educational attainment. On one hand, it is possible that a crowding of the low-skill labor market by immigrants galvanizes low-skill natives into becoming skilled and leads to increased educational attainment. On the other hand, it is also possible that a flood of low-skill immigrants attracts low-skill labor-intensive industries and firms to the area. These firms may create low-skill jobs in the area that incentivize individuals away from education. Still more, there is also the possibility that the immigrants may be the highly skilled ones, encouraging natives to pursue low-skill occupations because they cannot or do not want to compete with immigrants. Luckily, I have the data to determine immigration's impacts on educational attainment.

The Ordinary Least Squares results for educational attainment are presented in Table 3. My simple OLS regression reported in column (1) reveals a positive and significant correlation between immigrant share of population and educational attainment. Adding in my time and location variables qualifies the impact, but even up through the more restrictive specification reported in column (4) I maintain a positive and significant effect of immigrant share on educational attainment, encouraging the belief that low-skill immigrants provide natives with an incentive to become skilled or that the immigrants that arrive are skilled themselves. However, adding fixed effects (holding characteristics 
of a particular state constant) in the regression specification found in column (5) lowers the coefficient on immigrant share and removes its significance, suggesting that educational attainment is determined by the unobserved characteristics of a particular state rather than the number of immigrants in the area.

I note several additional results of interest in my education regressions. First, up until I add fixed effects found in column (5), the coefficient on unemployment is negative and significant, implying that as unemployment increases, fewer individuals seek out education. On the surface, this effect seems counterintuitive. As it is one of the few concrete ways to improve job prospects, I would expect workers to seek out education when unemployment levels increase. One possible explanation for this result is that this is not a causal effect and that I am simply capturing a strong spatial correlation between low education levels and low employment levels across U.S. states. Alternatively, the counterintuitive effect of unemployment on educational attainment can be attributed to the protracted process of earning an education. Earning a degree takes time. Because the data is measured decennially, and because it classifies individuals by attainment of a bachelor's degree or its equivalent in the same year in which unemployment is measured, it is unlikely that my regression estimate can capture the long run effects of unemployment on education. For example, when unemployment is high in a particular year, workers may gravitate towards education, but it typically takes several years before they complete their degree and are counted among the educated populace. Thus, I believe that the inability of my data set to capture the non-contemporaneous effects of unemployment lead to the counterintuitive sign on my estimated coefficient. 
Table 3: Effects of Immigration on Educational Attainment (OLS)

\begin{tabular}{|c|c|c|c|c|c|}
\hline VARIABLES & $\begin{array}{c}\text { (1) } \\
\text { Basic }\end{array}$ & $\begin{array}{c}\text { (2) } \\
\text { Labor Shocks }\end{array}$ & $\begin{array}{c}\text { (3) } \\
\text { Income } \\
\text { Shocks }\end{array}$ & $\begin{array}{c}\text { (4) } \\
\text { Location and } \\
\text { Population } \\
\text { Characteristics }\end{array}$ & $\begin{array}{c}5) \\
\text { State Fixed } \\
\text { Effects }\end{array}$ \\
\hline Immigrant Share & $\begin{array}{l}0.762^{* * *} \\
(0.0922)\end{array}$ & $\begin{array}{l}0.793^{* * *} \\
(0.0930)\end{array}$ & $\begin{array}{l}0.429^{* * *} \\
(0.0851)\end{array}$ & $\begin{array}{c}0.550^{* * * *} \\
(0.136)\end{array}$ & $\begin{array}{c}0.224 \\
(0.171)\end{array}$ \\
\hline Recession Months & & $\begin{array}{l}0.222^{* * *} \\
(0.0823)\end{array}$ & $\begin{array}{c}0.0583 \\
(0.0726)\end{array}$ & $\begin{array}{c}0.0592 \\
(0.0675)\end{array}$ & \\
\hline Unemployment Rate & & $\begin{array}{c}-0.553^{* * *} \\
(0.186)\end{array}$ & $\begin{array}{c}-0.583^{* * *} \\
(0.134)\end{array}$ & $\begin{array}{c}-0.517^{* * * *} \\
(0.138)\end{array}$ & $\begin{array}{c}0.127 \\
(0.175)\end{array}$ \\
\hline Average Housing Price & & & $\begin{array}{l}0.0207^{* * *} \\
(0.00616)\end{array}$ & $\begin{array}{l}0.0182^{* * *} \\
(0.00633)\end{array}$ & $\begin{array}{c}0.00972 \\
(0.00895)\end{array}$ \\
\hline Consumer Price Index & & & $\begin{array}{l}0.035^{* * * *} \\
(0.00794)\end{array}$ & $\begin{array}{l}0.0387^{* * *} \\
(0.00799)\end{array}$ & \\
\hline Population & & & & $\begin{array}{l}-0.0194^{* *} \\
(0.00862)\end{array}$ & $\begin{array}{c}-0.0509^{* *} \\
(0.0250)\end{array}$ \\
\hline Latitude Zones & No & No & No & Yes & No \\
\hline Year Dummies & No & No & No & No & Yes \\
\hline State Fixed Effects & No & No & No & No & Yes \\
\hline Constant & $\begin{array}{l}0.158^{* * *} \\
(0.00599)\end{array}$ & $\begin{array}{l}0.155^{* * *} \\
(0.0143)\end{array}$ & $\begin{array}{c}0.118^{* * *} \\
(0.00981)\end{array}$ & $\begin{array}{c}0.391^{* * *} \\
(0.100)\end{array}$ & $\begin{array}{l}0.803^{* *} \\
(0.349)\end{array}$ \\
\hline $\begin{array}{l}\text { Observations } \\
\text { R-squared } \\
\text { Number of state }\end{array}$ & $\begin{array}{c}255 \\
0.311\end{array}$ & $\begin{array}{c}255 \\
0.338\end{array}$ & $\begin{array}{c}255 \\
0.548\end{array}$ & $\begin{array}{c}255 \\
0.600\end{array}$ & $\begin{array}{c}255 \\
0.885 \\
51\end{array}$ \\
\hline
\end{tabular}

Robust standard errors in parentheses

${ }^{* * *} \mathrm{p}<0.01,{ }^{* *} \mathrm{p}<0.05,{ }^{*} \mathrm{p}<0.1$

Next, I examine the impact of immigration on wages. As with educational attainment, I can easily generate plausible explanations for the sign on immigration going either way. Perhaps immigration increases wages because the influx of low-skill workers, and the possibility of a complementarity effect, prompt a specialization across the worker types. Specialization will lead to a more productive economy, and to increased wages as each worker's marginal product of labor increases. Conversely, immigration could depress wages in keeping with the commonly cited narrative that immigrants flood the market; in a simple supply and demand framework, the increase in labor supply will decrease wages. In my econometric analysis, I will look at the interplay between immigration and several measures of wages to resolve this question.

The simple OLS results for overall, high-skill, and low-skill wages are presented in Tables 4, 5, and 6, respectively. Analysis of the OLS results reported in each table reveals a positive and significant impact of increased immigrant share on wages. With one 
exception, whereupon the effect is reduced and loses some of its significance, the estimated effect of immigration on wages remains positive and significant even in the most restrictive specification with year dummies and state fixed effects. These results largely dispute the idea that immigrants increase labor supply by a significant amount. It is possible that the addition of immigrants to the total labor supply is significant, but is offset by a consumption effect. As immigrants arrive in the country, rather than behaving as robots that work non-stop, they also become consumers in their own right. Their purchase of goods and services increases local consumer demand. Firms can react to this increased demand by ramping up outputs and building new factories. As a result, it is possible that immigration generates a long-run jump in labor demand that parallels the increase in labor supply. These two effects potentially balance each other out resulting in a positive or neutral net change in wages.

Table 4: Effects of Immigration on Wages (OLS)

\begin{tabular}{|c|c|c|c|c|c|}
\hline Variables & $\begin{array}{c}\text { (1) } \\
\text { Basic }\end{array}$ & $\begin{array}{c}\text { (2) } \\
\text { Labor Shocks }\end{array}$ & $\begin{array}{l}\text { (3) } \\
\text { Income } \\
\text { Shocks }\end{array}$ & $\begin{array}{c}\text { (4) } \\
\text { Location and } \\
\text { Population } \\
\text { Characteristics } \\
\end{array}$ & $\begin{array}{c}(5) \\
\text { State Fixed } \\
\text { Effects }\end{array}$ \\
\hline Immigrant Share & $\begin{array}{c}1.222^{* * *} \\
(0.115)\end{array}$ & $\begin{array}{c}1.257^{* * *} \\
(0.115)\end{array}$ & $\begin{array}{c}0.954^{* * *} \\
(0.109)\end{array}$ & $\begin{array}{c}4.474^{* * * *} \\
(1.085)\end{array}$ & $\begin{array}{l}3.479^{* *} \\
(1.680)\end{array}$ \\
\hline Recession Months & & $\begin{array}{c}-0.569^{* * * *} \\
(0.117)\end{array}$ & $\begin{array}{c}-0.597^{* * * *} \\
(0.103)\end{array}$ & $\begin{array}{c}-0.659^{* * * *} \\
(0.0878)\end{array}$ & \\
\hline Unemployment Rate & & $\begin{array}{c}-0.0563 \\
(0.355)\end{array}$ & $\begin{array}{c}0.390 \\
(0.298)\end{array}$ & $\begin{array}{c}0.354 \\
(0.261)\end{array}$ & $\begin{array}{c}0.331 \\
(0.340)\end{array}$ \\
\hline Average Housing Price & & & $\begin{array}{c}0.0333^{* * *} \\
(0.0104)\end{array}$ & $\begin{array}{l}0.0392^{* * *} \\
(0.00942)\end{array}$ & $\begin{array}{c}0.0477^{* * *} \\
(0.0114)\end{array}$ \\
\hline Consumer Price Index & & & $\begin{array}{c}-0.108^{* * * *} \\
(0.0147)\end{array}$ & $\begin{array}{c}-0.0988^{* * * *} \\
(0.0128)\end{array}$ & \\
\hline Educated Worker Share & & & $\begin{array}{c}0.672^{* * *} \\
(0.149)\end{array}$ & $\begin{array}{c}0.599^{* * *} \\
(0.119)\end{array}$ & $\begin{array}{c}0.316 \\
(0.244)\end{array}$ \\
\hline Population & & & & $\begin{array}{l}0.0447^{* * *} \\
(0.00618)\end{array}$ & $\begin{array}{c}0.0347 \\
(0.0501)\end{array}$ \\
\hline Remittances*Immigration & & & & $\begin{array}{l}-0.183^{* * *} \\
(0.0493)\end{array}$ & $\begin{array}{l}-0.145^{* *} \\
(0.0696)\end{array}$ \\
\hline Latitude Zone & No & No & No & Yes & No \\
\hline Year Dummies & No & No & No & No & Yes \\
\hline State Fixed Effects & No & No & No & No & Yes \\
\hline Constant & $\begin{array}{l}10.03^{* * * *} \\
(0.0101)\end{array}$ & $\begin{array}{l}10.12^{* * *} \\
(0.0208)\end{array}$ & $\begin{array}{l}10.09^{* * * *} \\
(0.0264)\end{array}$ & $\begin{array}{c}9.548^{* * * *} \\
(0.106)\end{array}$ & $\begin{array}{c}9.524^{* * *} \\
(0.692)\end{array}$ \\
\hline $\begin{array}{l}\text { Observations } \\
\text { R-squared } \\
\text { Number of state }\end{array}$ & $\begin{array}{c}255 \\
0.347\end{array}$ & $\begin{array}{c}255 \\
0.419\end{array}$ & $\begin{array}{c}255 \\
0.568\end{array}$ & $\begin{array}{c}255 \\
0.705\end{array}$ & $\begin{array}{c}255 \\
0.526 \\
51 \\
\end{array}$ \\
\hline
\end{tabular}

Robust standard errors in parentheses

*** $\mathrm{p}<0.01,{ }^{* *} \mathrm{p}<0.05,{ }^{*} \mathrm{p}<0.1$ 
Table 5: Effects of Immigration on High-Skill Wages (OLS)

\begin{tabular}{|c|c|c|c|c|c|}
\hline Variables & $\begin{array}{c}(1) \\
\text { Basic }\end{array}$ & $\begin{array}{c}(2) \\
\text { Labor Shocks }\end{array}$ & $\begin{array}{c}\text { (3) } \\
\text { Income } \\
\text { Shocks }\end{array}$ & $\begin{array}{c}\text { (4) } \\
\text { Location and } \\
\text { Population } \\
\text { Characteristics }\end{array}$ & $\begin{array}{c}5) \\
\text { State Fixed } \\
\text { Effects }\end{array}$ \\
\hline Immigrant Share & $\begin{array}{c}0.737^{* * *} \\
(0.103)\end{array}$ & $\begin{array}{l}0.730^{* * *} \\
(0.0994)\end{array}$ & $\begin{array}{c}0.820^{* * *} \\
(0.102)\end{array}$ & $\begin{array}{c}3.086 * * * \\
(1.046)\end{array}$ & $\begin{array}{c}0.991 \\
(1.618)\end{array}$ \\
\hline Recession Months & & $\begin{array}{c}-1.016^{* * *} \\
(0.126)\end{array}$ & $\begin{array}{c}-0.897^{* * *} \\
(0.0989)\end{array}$ & $\begin{array}{l}-0.945^{* * *} \\
(0.0840)\end{array}$ & \\
\hline Unemployment Rate & & $\begin{array}{l}0.818^{* *} \\
(0.382)\end{array}$ & $\begin{array}{l}1.155^{* * *} \\
(0.268)\end{array}$ & $\begin{array}{c}1.008^{* * *} \\
(0.247)\end{array}$ & $\begin{array}{c}0.117 \\
(0.304)\end{array}$ \\
\hline Average Housing Price & & & $\begin{array}{l}0.0358^{* * *} \\
(0.00968)\end{array}$ & $\begin{array}{l}0.0480^{* * *} \\
(0.00894)\end{array}$ & $\begin{array}{c}0.0402^{* * * *} \\
(0.0110)\end{array}$ \\
\hline Consumer Price Index & & & $\begin{array}{l}-0.151^{* * *} \\
(0.0131)\end{array}$ & $\begin{array}{c}-0.158^{* * * *} \\
(0.0113)\end{array}$ & \\
\hline Educated Worker Share & & & $\begin{array}{c}0.417^{* * *} \\
(0.114)\end{array}$ & $\begin{array}{l}0.459^{* * * *} \\
(0.0971)\end{array}$ & $\begin{array}{l}0.448^{*} \\
(0.258)\end{array}$ \\
\hline Population & & & & $\begin{array}{l}0.0555^{* * *} \\
(0.00623)\end{array}$ & $\begin{array}{l}0.0959^{* * *} \\
(0.0467)\end{array}$ \\
\hline Remittances* Immigration & & & & $\begin{array}{l}-0.132^{* * *} \\
(0.0475)\end{array}$ & $\begin{array}{l}-0.0436 \\
(0.0665)\end{array}$ \\
\hline Latitude Zone & No & No & No & Yes & No \\
\hline Year Dummies & No & No & No & No & Yes \\
\hline State Fixed Effects & No & No & No & No & Yes \\
\hline Constant & $\begin{array}{l}10.21^{* * *} \\
(0.0113)\end{array}$ & $\begin{array}{l}10.31^{* * *} \\
(0.0227)\end{array}$ & $\begin{array}{l}10.35^{* * *} \\
(0.0226)\end{array}$ & $\begin{array}{c}9.693^{* * *} \\
(0.100)\end{array}$ & $\begin{array}{l}8.951^{* * *} \\
(0.642)\end{array}$ \\
\hline $\begin{array}{l}\text { Observations } \\
\text { R-squared } \\
\text { Number of state }\end{array}$ & $\begin{array}{c}255 \\
0.131\end{array}$ & $\begin{array}{c}255 \\
0.325\end{array}$ & $\begin{array}{c}255 \\
0.576\end{array}$ & $\begin{array}{c}255 \\
0.714\end{array}$ & $\begin{array}{c}255 \\
0.770 \\
51\end{array}$ \\
\hline
\end{tabular}

Robust standard errors in parentheses

$$
{ }^{* * *} \mathrm{p}<0.01,{ }^{* *} \mathrm{p}<0.05,{ }^{*} \mathrm{p}<0.1
$$

I also include an interaction term between immigration and state-level remittances to test Borjas' hypothesis that immigrants looking to send remittances to their home countries initiate greater wage reductions. In each of Tables 4, 5, and 6, the coefficient on the interaction term is negative and significant, lending credence to Borjas theory: if we hold the variable immigrant share constant across two states, the state paying higher remittances will see decreased wages across the board.

We acknowledge the likelihood for endogeneity to arise in this case. Wages in a particular area can affect the number and type of immigrants that settle in that area, while immigrant demographics in turn alter the local wages. In this scenario, it is 
difficult to establish a causal relationship. I use Two Stage Least Squares (2SLS) methodology to tackle our potential endogeneity issue.

Table 6: Effects of Immigration on Low-Skill Wages (OLS)

\begin{tabular}{|c|c|c|c|c|c|}
\hline Variables & $\begin{array}{c}(1) \\
\text { Basic }\end{array}$ & $\begin{array}{c}\text { (2) } \\
\text { Labor } \\
\text { Shocks }\end{array}$ & $\begin{array}{c}\text { (3) } \\
\text { Income } \\
\text { Shocks }\end{array}$ & $\begin{array}{c}\text { (4) } \\
\text { Location and } \\
\text { Population } \\
\text { Characteristics }\end{array}$ & $\begin{array}{c}5) \\
\text { State Fixed } \\
\text { Effects }\end{array}$ \\
\hline Immigrant Share & $\begin{array}{c}0.230^{* *} \\
(0.104)\end{array}$ & $\begin{array}{c}0.277^{* * *} \\
(0.105)\end{array}$ & $\begin{array}{c}0.616^{* * * *} \\
(0.114)\end{array}$ & $\begin{array}{c}4.847^{* * *} \\
(1.015)\end{array}$ & $\begin{array}{l}2.356^{*} \\
(1.302)\end{array}$ \\
\hline Recession Months & & $\begin{array}{c}-0.746^{* * * *} \\
(0.148)\end{array}$ & $\begin{array}{c}-0.539^{* * * *} \\
(0.109)\end{array}$ & $\begin{array}{c}-0.606^{* * *} \\
(0.0901)\end{array}$ & \\
\hline Unemployment Rate & & $\begin{array}{c}-0.0873 \\
(0.463)\end{array}$ & $\begin{array}{c}0.164 \\
(0.325)\end{array}$ & $\begin{array}{c}0.153 \\
(0.267)\end{array}$ & $\begin{array}{c}-0.0285 \\
(0.396)\end{array}$ \\
\hline Average Housing Price & & & $\begin{array}{l}0.0226^{* *} \\
(0.0106)\end{array}$ & $\begin{array}{l}0.0269^{* * *} \\
(0.00848)\end{array}$ & $\begin{array}{l}0.0307^{* * *} \\
(0.00871)\end{array}$ \\
\hline Consumer Price Index & & & $\begin{array}{c}-0.152^{* * * *} \\
(0.0159)\end{array}$ & $\begin{array}{l}-0.134^{* * *} \\
(0.0133)\end{array}$ & \\
\hline Educated Worker Share & & & $\begin{array}{l}0.257^{* *} \\
(0.128)\end{array}$ & $\begin{array}{c}0.107 \\
(0.0888)\end{array}$ & $\begin{array}{l}0.296^{* *} \\
(0.129)\end{array}$ \\
\hline Population & & & & $\begin{array}{l}0.0382^{* * *} \\
(0.00674)\end{array}$ & $\begin{array}{l}0.0951^{* *} \\
(0.0426)\end{array}$ \\
\hline Remittances* Immigration & & & & $\begin{array}{l}-0.213^{* * * *} \\
(0.0462)\end{array}$ & $\begin{array}{l}-0.119^{* *} \\
(0.0555)\end{array}$ \\
\hline Latitude Zone & No & No & No & Yes & No \\
\hline Year Dummies & No & No & No & No & Yes \\
\hline State Fixed Effects & No & No & No & No & Yes \\
\hline Constant & $\begin{array}{l}9.879^{* * *} \\
(0.0117)\end{array}$ & $\begin{array}{l}9.997^{* * *} \\
(0.0226)\end{array}$ & $\begin{array}{l}10.07^{* * *} \\
(0.0272)\end{array}$ & $\begin{array}{c}9.639^{* * * *} \\
(0.111)\end{array}$ & $\begin{array}{c}8.626^{* * *} \\
(0.589)\end{array}$ \\
\hline $\begin{array}{l}\text { Observations } \\
\text { R-squared } \\
\text { Number of state }\end{array}$ & $\begin{array}{c}255 \\
0.013\end{array}$ & $\begin{array}{c}255 \\
0.145\end{array}$ & $\begin{array}{c}255 \\
0.484\end{array}$ & $\begin{array}{c}255 \\
0.671\end{array}$ & $\begin{array}{c}255 \\
0.729 \\
51\end{array}$ \\
\hline
\end{tabular}

Robust standard errors in parentheses

$$
{ }^{* * *} \mathrm{p}<0.01,{ }^{* *} \mathrm{p}<0.05,{ }^{*} \mathrm{p}<0.1
$$

We created and ran regressions with a number of exogenous instruments before settling on the use of the immigrant share of state population lagged 20 years. Lagged immigrant share qualifies as a valid instrument because it is highly correlated with current state-level shares of immigration. We know that migrants tend to settle in communities where previous migrants have already established themselves (Dunleavy and Gemery, 1977). Figure 3 demonstrates this tendency, showing the strong positive correlation between a state's immigrant population lagged 20 years, and the change in 
immigration over the 20 years since. As you can see, states with large lagged immigrant populations have an increased likelihood of having large immigrant populations today. Moreover, the lagged immigrant share is an exogenous instrument, one uncorrelated with the residual term from the wage regression. This is because it is unlikely that wages in a specific place and time will have an impact on the immigrant population in that place 20 years previous. I now have an exogenous indicator of immigrant share in a location and can conduct 2SLS estimation, to avoid the endogeneity problem.

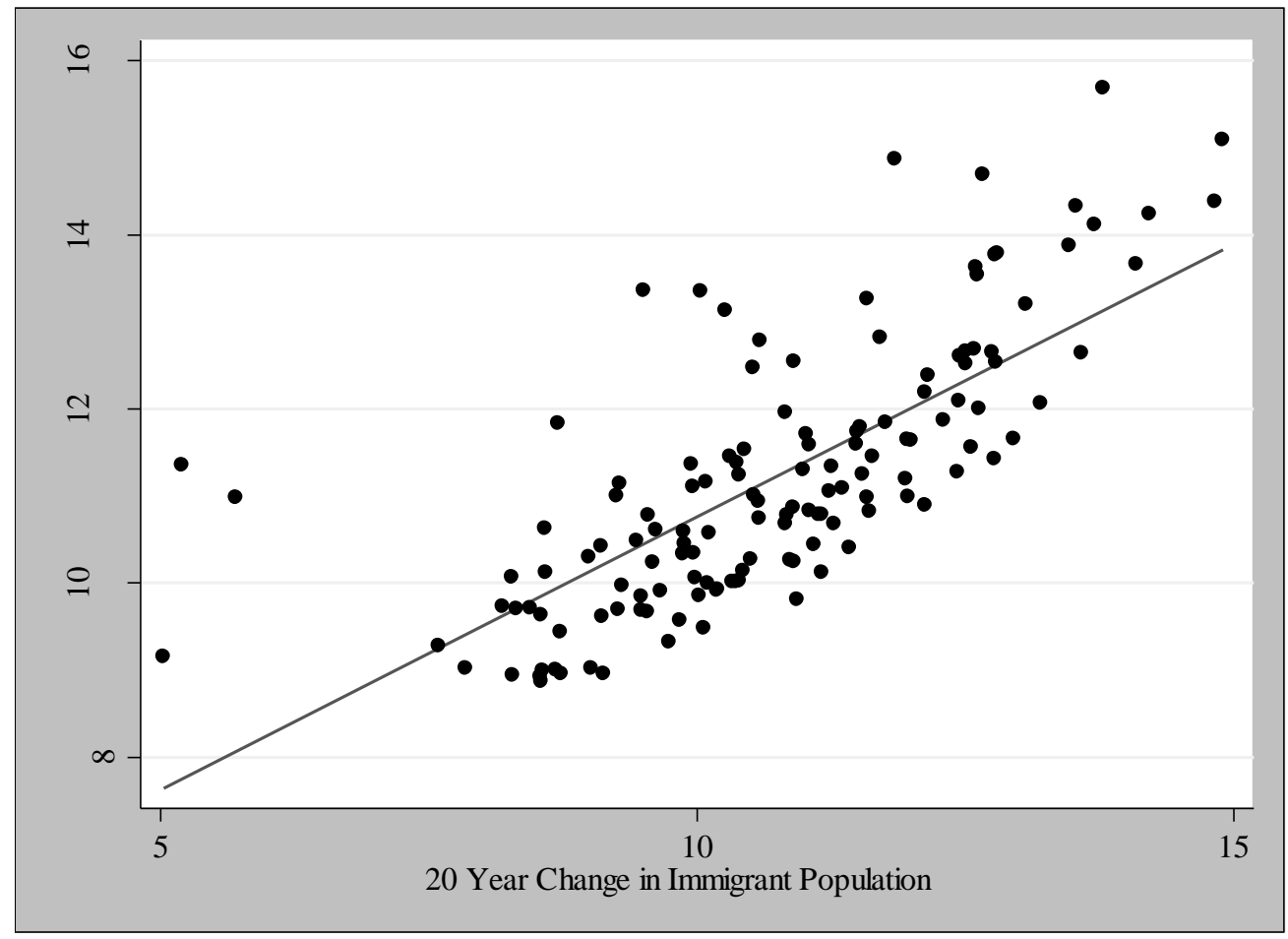

Figure 3: Correlation Between Lagged Immigrant Population and Change Over Time

The results of my 2SLS estimation using 20-year lagged immigrant share as an instrument are presented in Table 7. I find positive but largely insignificant effects of immigration on wages across all skill levels. The insignificance of my estimated coefficients suggests one of two things: much of the positive correlation I found earlier was indeed the result of endogeneity rather than a causal effect, or the lagged immigrant share is not as good an instrument as I thought. I ran into similar significance issues when implementing the estimation with other (unreported) instruments, and was unable to find an instrument to provide us with conclusive results. Because I could not determine a suitable instrument, I believe additional work needs to be done using the 2SLS methodology before I can establish a robust conclusion regarding the true causality of immigration on wages. I leave the determination of a suitable instrument and the conducting of the additional 2SLS estimation to future versions of this study. 
Table 7: Effects of Immigration on Wages Across Skill Levels (2SLS)

\begin{tabular}{|c|c|c|c|}
\hline VARIABLES & $\begin{array}{c}(1) \\
\text { Annual Wages } \\
\end{array}$ & $\begin{array}{c}(2) \\
\text { High-Skill Wages }\end{array}$ & $\begin{array}{c}\text { (3) } \\
\text { Low-Skill Wages }\end{array}$ \\
\hline Immigrant Share & $\begin{array}{l}0.882^{*} \\
(0.452)\end{array}$ & $\begin{array}{c}0.146 \\
(0.300)\end{array}$ & $\begin{array}{c}0.331 \\
(0.392)\end{array}$ \\
\hline Unemployment Rate & $\begin{array}{r}-0.0847 \\
(0.373)\end{array}$ & $\begin{array}{c}0.0174 \\
(0.338)\end{array}$ & $\begin{array}{l}-0.490 \\
(0.417)\end{array}$ \\
\hline Average Housing Price & $\begin{array}{l}0.0335^{* * *} \\
(0.00972)\end{array}$ & $\begin{array}{l}0.0422^{* * *} \\
(0.00739)\end{array}$ & $\begin{array}{c}0.0161^{*} \\
(0.00933)\end{array}$ \\
\hline Population & $\begin{array}{l}-0.0225 \\
(0.0512)\end{array}$ & $\begin{array}{l}0.0787^{*} \\
(0.0415)\end{array}$ & $\begin{array}{c}0.0446 \\
(0.0427)\end{array}$ \\
\hline Year Dummies & Yes & Yes & Yes \\
\hline State Fixed Effects & Yes & Yes & Yes \\
\hline Observations & 253 & 253 & 253 \\
\hline R-squared & 0.448 & 0.749 & 0.691 \\
\hline Number of state & 51 & 51 & 51 \\
\hline
\end{tabular}

Finally, I move to the analysis of the impacts of immigration on native employment. Yet again, there are plausible explanations for immigration having either a positive or a negative effect on native employment. There is the same potential for complementarity that we saw in my discussion of the wage effects of immigration. This complementarity and the resultant specialization effect would increase the number of available jobs leading to an increase in natives being employed. In contrast, immigration could have a negative impact on native employment because of the increased labor supply. Assuming that the number of jobs is constant, that firms are not attracted to the increased labor force, and that specialization does not occur, then the existing jobs will be allocated among natives and immigrants by some combination of skill and random luck. If this is the case, it follows that native employment will fall because at least some of the fixed number of jobs will be transferred to immigrants.

The results of my OLS estimation of this model can be found in Tables 8, 9, and 10, arranged by total native employment, high-skill native employment, and low-skill native employment, respectively. Several coefficient estimates stand out immediately. Each model reports a positive and significant effect of immigrant share on native employment until I control for state characteristics beginning in the regression specification reported in column (4), at which point the sign changes. At first glance, it may seem that my model was simply underspecified until that point and the more accurate impact of immigrant share is the one reported in regressions (4) and (5). However, I do not think this is the case. Nor is it the case that the specifications in columns (4) and (5) are over-specified and report inaccurate estimates. Rather, I believe that the estimated coefficients in 
columns (3) and (4) simply present different effects. In controlling for both state education and population in column (4), I essentially control for total labor supply. Adding in a control for wages means I have pegged the intersection of labor supply and labor demand at a certain point (corresponding to a particular wage level). As a result, the market captured by the regression specification in column (4) has a fixed number of jobs and the only source of variation left for model identification is the composition of the labor force. In this case, it is obvious that increasing the immigrant share of the labor force will lead to a decrease in native employment. In this way, regression (4) simply captures a substitution effect of immigration.

Table 8: Effects of Immigration on Native Employment (OLS)

\begin{tabular}{|c|c|c|c|c|c|}
\hline VARIABLES & $\begin{array}{c}(1) \\
\text { Basic }\end{array}$ & $\begin{array}{c}\text { (2) } \\
\text { Labor } \\
\text { Shocks }\end{array}$ & $\begin{array}{c}\text { (3) } \\
\text { Income } \\
\text { Shocks }\end{array}$ & $\begin{array}{c}\text { (4) } \\
\text { Location and } \\
\text { Population } \\
\text { Characteristics } \\
\end{array}$ & $\begin{array}{c}5) \\
\text { State Fixed } \\
\text { Effects }\end{array}$ \\
\hline Immigrant Share & $\begin{array}{c}5.750^{* * *} \\
(0.868)\end{array}$ & $\begin{array}{c}5.720^{* * *} \\
(0.872)\end{array}$ & $\begin{array}{c}5 \cdot 368 * * * \\
(1.458)\end{array}$ & $\begin{array}{l}-1.293^{* * *} \\
(0.0569)\end{array}$ & $\begin{array}{c}-1.430^{* * *} \\
(0.0743)\end{array}$ \\
\hline Annual Wages & & & $\begin{array}{c}0.596 \\
(0.695)\end{array}$ & $\begin{array}{c}0.0881^{* * * *} \\
(0.0332)\end{array}$ & $\begin{array}{c}0.0349 \\
(0.0382)\end{array}$ \\
\hline Recession Months & & $\begin{array}{c}0.558 \\
(0.941)\end{array}$ & $\begin{array}{c}0.973 \\
(1.034)\end{array}$ & $\begin{array}{c}0.0471 \\
(0.0455)\end{array}$ & \\
\hline Average Housing Price & & & $\begin{array}{c}-0.235^{* *} \\
(0.114)\end{array}$ & $\begin{array}{c}-0.0204^{* * *} \\
(0.00528)\end{array}$ & $\begin{array}{l}-0.00320 \\
(0.00390)\end{array}$ \\
\hline Consumer Price Index & & & $\begin{array}{l}0.354^{* * *} \\
(0.158)\end{array}$ & $\begin{array}{l}0.0605^{* * *} \\
(0.00910)\end{array}$ & \\
\hline Educated Worker Share & & & & $\begin{array}{l}0.185^{*} \\
(0.105)\end{array}$ & $\begin{array}{l}-0.0497 \\
(0.0926)\end{array}$ \\
\hline Population & & & & $\begin{array}{l}0.996^{* * *} \\
(0.00340)\end{array}$ & $\begin{array}{l}0.987^{* * *} \\
(0.0166)\end{array}$ \\
\hline Latitude Zone & No & No & No & Yes & No \\
\hline Year Dummies & No & No & No & No & Yes \\
\hline State Fixed Effects & No & No & No & No & Yes \\
\hline Constant & $\begin{array}{l}13.54^{* * *} \\
(0.0823)\end{array}$ & $\begin{array}{c}13.46^{* * * *} \\
(0.168)\end{array}$ & $\begin{array}{c}7.238 \\
(7.044)\end{array}$ & $\begin{array}{c}-1.121^{* * *} \\
(0.321)\end{array}$ & $\begin{array}{c}-0.419 \\
(0.355)\end{array}$ \\
\hline $\begin{array}{l}\text { Observations } \\
\text { R-squared } \\
\text { Number of state }\end{array}$ & $\begin{array}{c}255 \\
0.138\end{array}$ & $\begin{array}{c}255 \\
0.139\end{array}$ & $\begin{array}{c}255 \\
0.157\end{array}$ & $\begin{array}{c}255 \\
0.998\end{array}$ & $\begin{array}{c}255 \\
0.997 \\
51 \\
\end{array}$ \\
\hline
\end{tabular}

Robust standard errors in parentheses

*** $\mathrm{p}<0.01,{ }^{* *} \mathrm{p}<0.05,{ }^{*} \mathrm{p}<0.1$

On the other hand, regression (3) leaves many of the above labor market controls out. This allows the model to account for fluctuations in the number of jobs available as well as in the composition of the labor force. In this way, the model specified in column (3) captures potential complementarity effects of immigration in addition to the substitution effects. That this nets out to be large and positive is evidence of an overwhelming complementarity effect that more than outweighs the substitution effects of immigration. 
In short, I find that the net native employment gains more than make up for the losses when considering increased immigration.

Another point of interest resulting from the study's employment regressions is the nearly one-to-one ratio between an increase in population and an increase in employment across each skill level. This coefficient makes intuitive sense given the data set construction: all of the population data from the Basso-Peri data set is limited to individuals ages 18-64. It follows then that an increase in the population variables results in an increase in employment because I am increasing the number of workers rather than the general populace.

Table 9: Effects of Immigration on High-Skill Native Employment (OLS)

\begin{tabular}{|c|c|c|c|c|c|}
\hline VARIABLES & $\begin{array}{c}\text { (1) } \\
\text { Basic }\end{array}$ & $\begin{array}{c}\text { (2) } \\
\text { Labor } \\
\text { Shocks }\end{array}$ & $\begin{array}{c}\text { (3) } \\
\text { Income } \\
\text { Shocks }\end{array}$ & $\begin{array}{c}\text { (4) } \\
\text { Location and } \\
\text { Population } \\
\text { Characteristics }\end{array}$ & $\begin{array}{c}5) \\
\text { State Fixed } \\
\text { Effects }\end{array}$ \\
\hline Immigrant Share & $\begin{array}{c}8.496^{* * *} \\
(0.840)\end{array}$ & $\begin{array}{c}8.400^{* * *} \\
(0.842)\end{array}$ & $\begin{array}{c}4.172^{* * *} \\
(1.482)\end{array}$ & $\begin{array}{c}-0.384^{*} \\
(0.231)\end{array}$ & $\begin{array}{c}-1.719^{* * *} \\
(0.328)\end{array}$ \\
\hline High-Skill Wages & & & $\begin{array}{c}2.766^{* * *} \\
(0.738)\end{array}$ & $\begin{array}{c}-0.333^{* * * *} \\
(0.121)\end{array}$ & $\begin{array}{l}0.0346 \\
(0.108)\end{array}$ \\
\hline Recession Months & & $\begin{array}{l}1.767^{*} \\
(0.974)\end{array}$ & $\begin{array}{c}3.056^{* * * *} \\
(1.060)\end{array}$ & $\begin{array}{c}0.169 \\
(0.176)\end{array}$ & \\
\hline Average Housing Price & & & $\begin{array}{c}-0.350^{* * * *} \\
(0.117)\end{array}$ & $\begin{array}{c}-0.0624^{* * * *} \\
(0.0216)\end{array}$ & $\begin{array}{l}0.00188 \\
(0.0100)\end{array}$ \\
\hline Consumer Price Index & & & $\begin{array}{c}1.055^{* * * *} \\
(0.171)\end{array}$ & $\begin{array}{l}0.351^{* * *} \\
(0.0372)\end{array}$ & \\
\hline Educated Worker Share & & & & $\begin{array}{c}1.522^{* * *} \\
(0.405)\end{array}$ & $\begin{array}{c}-0.0496 \\
(0.179)\end{array}$ \\
\hline Population & & & & $\begin{array}{l}1.009^{* * * *} \\
(0.0135)\end{array}$ & $\begin{array}{l}0.840^{* * * *} \\
(0.0641)\end{array}$ \\
\hline Latitude Zone & No & No & No & Yes & No \\
\hline Year Dummies & No & No & No & No & Yes \\
\hline State Fixed Effects & No & No & No & No & Yes \\
\hline Constant & $\begin{array}{l}12.60^{* * *} \\
(0.0840)\end{array}$ & $\begin{array}{c}12.34^{* * *} \\
(0.179)\end{array}$ & $\begin{array}{c}-16.98^{* *} \\
(7.677)\end{array}$ & $\begin{array}{c}1.584 \\
(1.192)\end{array}$ & $\begin{array}{c}0.318 \\
(0.875)\end{array}$ \\
\hline $\begin{array}{l}\text { Observations } \\
\text { R-squared } \\
\text { Number of state }\end{array}$ & $\begin{array}{c}255 \\
0.248\end{array}$ & $\begin{array}{c}255 \\
0.257\end{array}$ & $\begin{array}{c}255 \\
0.384\end{array}$ & $\begin{array}{c}255 \\
0.980\end{array}$ & $\begin{array}{c}255 \\
0.992 \\
51 \\
\end{array}$ \\
\hline
\end{tabular}


Table 10: Effects of Immigration on Low-Skill Native Employment (OLS)

\begin{tabular}{|c|c|c|c|c|c|}
\hline VARIABLES & $\begin{array}{c}\text { (1) } \\
\text { Basic }\end{array}$ & $\begin{array}{c}\text { (2) } \\
\text { Labor } \\
\text { Shocks }\end{array}$ & $\begin{array}{c}\text { (3) } \\
\text { Income } \\
\text { Shocks }\end{array}$ & $\begin{array}{c}\text { (4) } \\
\text { Location and } \\
\text { Population } \\
\text { Characteristics }\end{array}$ & $\begin{array}{c}(5) \\
\text { State Fixed } \\
\text { Effects }\end{array}$ \\
\hline Immigrant Share & $\begin{array}{c}2.949^{* * *} \\
(0.952)\end{array}$ & $\begin{array}{c}2.959^{* * *} \\
(0.955)\end{array}$ & $\begin{array}{c}4.830^{* * * *} \\
(1.266)\end{array}$ & $\begin{array}{c}-2.267^{* * *} \\
(0.118)\end{array}$ & $\begin{array}{c}-1.975^{* * *} \\
(0.205)\end{array}$ \\
\hline Low-Skill Wages & & & $\begin{array}{c}0.197 \\
(0.702)\end{array}$ & $\begin{array}{c}0.114^{* *} \\
(0.0533)\end{array}$ & $\begin{array}{c}0.156^{* *} \\
(0.0680)\end{array}$ \\
\hline Recession Months & & $\begin{array}{c}-0.178 \\
(0.995)\end{array}$ & $\begin{array}{c}0.789 \\
(1.083)\end{array}$ & $\begin{array}{c}0.0581 \\
(0.0787)\end{array}$ & \\
\hline Average Housing Price & & & $\begin{array}{c}-0.238^{* * *} \\
(0.116)\end{array}$ & $\begin{array}{c}-0.0143 \\
(0.0106)\end{array}$ & $\begin{array}{c}-0.0309^{* * *} \\
(0.0118)\end{array}$ \\
\hline Consumer Price Index & & & $\begin{array}{l}0.0524 \\
(0.187)\end{array}$ & $\begin{array}{l}-0.194^{* * * *} \\
(0.0169)\end{array}$ & \\
\hline Educated Worker Share & & & & $\begin{array}{c}-0.642^{* * *} \\
(0.137)\end{array}$ & $\begin{array}{l}-0.492 \\
(0.392)\end{array}$ \\
\hline Population & & & & $\begin{array}{l}1.008^{* * * *} \\
(0.00632)\end{array}$ & $\begin{array}{l}1.029^{* * *} \\
(0.0601)\end{array}$ \\
\hline Latitude Zone & No & No & No & Yes & No \\
\hline Year Dummies & No & No & No & No & Yes \\
\hline State Fixed Effects & No & No & No & No & Yes \\
\hline Constant & $\begin{array}{l}13.00^{* * *} \\
(0.0880)\end{array}$ & $\begin{array}{c}13.03^{* * *} \\
(0.176)\end{array}$ & $\begin{array}{c}11.12 \\
(7.075)\end{array}$ & $\begin{array}{c}-1.643^{* * *} \\
(0.521)\end{array}$ & $\begin{array}{c}-2.462^{* * *} \\
(0.815)\end{array}$ \\
\hline $\begin{array}{l}\text { Observations } \\
\text { R-squared } \\
\text { Number of state }\end{array}$ & $\begin{array}{c}255 \\
0.036\end{array}$ & $\begin{array}{c}255 \\
0.037\end{array}$ & $\begin{array}{c}255 \\
0.080\end{array}$ & $\begin{array}{c}255 \\
0.994\end{array}$ & $\begin{array}{c}255 \\
0.938 \\
51 \\
\end{array}$ \\
\hline
\end{tabular}

Robust standard errors in parentheses

*** $\mathrm{p}<0.01,{ }^{* *} \mathrm{p}<0.05,{ }^{*} \mathrm{p}<0.1$

Comparing Tables 9 and 10 gives us interesting, if somewhat predictable, insight into which worker types are most affected by immigration, and provides support for my earlier complementarity hypothesis. Recalling that the regression specification in column (4) of each table reports the substitution effect of immigration on native labor, we see that highskill native workers experience this effect much less drastically than their low-skill counterparts. The substitution coefficient of high-skill labor is a fraction of that of lowskill, and the high-skill estimate is nearly insignificant. This difference carries with it two important implications. First, immigrants tend to low-skill jobs upon arrival, resulting in significant displacement of native low-skill labor. Second, because immigrants tend towards low-skill jobs, there is at least an opportunity for complementarity to take place. It is unclear from these results whether this complementarity takes place in actuality, but knowledge of these immigrants' tendencies gives the idea plausibility. 
We again recognize the likelihood for endogeneity here. Immigrants are likely attracted to areas with high employment levels, while employment opportunities will be impacted by the number of immigrants in an area. As a result, I employ the 2SLS methodology using again my 20-year lagged immigrant share as an exogenous instrument. The results are presented in Table 11, using the model specification with year dummies and state level fixed effects. My 2SLS specification provides us with negative and significant effects of immigration on native employment across skill levels. I report only the substitution effect here and do not allow for the complementarity that I expressed in the OLS regressions. It is likely a result of separating out this substitution effect that we see such large negative values.

Table 11: Effects of Immigration on Native Employment Across Skill Levels (2SLS)

\begin{tabular}{lccc}
\hline VARIABLES & $\begin{array}{c}(1) \\
\text { Native Employment }\end{array}$ & $\begin{array}{c}(2) \\
\text { High-Skill Native } \\
\text { Employment }\end{array}$ & $\begin{array}{c}\text { Low-Skill Native } \\
\text { Employment }\end{array}$ \\
\hline Immigrant Share & $-1.737^{* * *}$ & $-2.022^{* * *}$ & $-1.637^{* * *}$ \\
Annual Wages & $(0.128)$ & $(0.432)$ & $(0.312)$ \\
High-Skill Wages & 0.0413 & & \\
& $(0.0319)$ & & \\
Low-Skill Wages & & $(0.0231$ & $0.168^{* *}$ \\
& & & $(0.0668)$ \\
Average Housing Price & & & $-0.0343^{* * *}$ \\
& 0.000630 & 0.00527 & $(0.0115)$ \\
Educated Worker Share & $(0.00387)$ & $(0.0105)$ & -0.581 \\
& 0.00642 & 0.0231 & $(0.487)$ \\
Population & $(0.0697)$ & $(0.209)$ & $1.003^{* * *}$ \\
& $1.015^{* * *}$ & $0.876^{* * *}$ & $(0.0613)$ \\
Year Dummies & $(0.0188)$ & $(0.0567)$ & Yes \\
Yes & Yes & Yes \\
State Fixed Effects & Yes & Yes & 253 \\
R-squared & 253 & 253 & 0.936 \\
Number of state & 0.996 & 0.992 & 51 \\
\hline
\end{tabular}

Robust standard errors in parentheses

*** $\mathrm{p}<0.01,{ }^{* *} \mathrm{p}<0.05,{ }^{*} \mathrm{p}<0.1$

\section{CONCLUSION}

Immigration policies represent one of the most delicate and contentious topics debated throughout the world. The dramatic increase in cross-border migration observed in the last few decades has generated significant interest among economists to understand 
the main economic implications of immigration for host countries. This study contributes to this debate by examining the effect of U.S. immigration on local labor markets.

According to my data and model estimation, it seems many of the negative impacts of large scale immigration have been grossly exaggerated. In many cases, I find significant evidence of positive correlation between immigration and the economic outcomes of interest, educational attainment, wages, and native employment. Much of the positive correlation appears robust, holding statistical significance as I control for skill level and even in my most restrictive regressions. I recognize areas for further work to be done, in particular identifying suitable instruments for use in my 2SLS regressions, however my results at this time provide no empirical support for, and indeed contest, the majority of the pessimistic narratives surrounding the ever-increasing rate of global migration.

\section{ACKNOWLEDGEMENTS}

This paper was prepared with the generous assistance of the University of Oregon Office of the Vice President for Research and Innovation. I would like to extend my thanks to Anca Cristea for providing advising, guidance, and expertise to this project.

\section{REFERENCES}

Borjas, George J. "The labor demand curve is downward sloping: Reexamining the impact of immigration on the labor market." The Quarterly Journal of Economics 118:4 (2003): 1335-1374

Borjas, George J. "The Analytics of the Wage Effect of Immigration." IZA Journal of Migration 2.1 (2013): 1-25. ProQuest. Web. 14 June 2016.

Borjas, George J., and Marta Tienda. "The Economic Consequences of Immigration." Science 235.4789 (1987): 645-51. JSTOR. Web. 13 June 2016.

Card, David. "Is the New Immigration Really So Bad?" The Economic Journal 115.507 (2005): F300-323. Wiley Online Library. Web. 15 June 2016.

Chiquiar, Daniel, and Gordon H. Hanson. "International Migration, Self-Selection, and the Distribution of Wages: Evidence from Mexico and the United States." Journal of Political Economy 113.2 (2005): 239-281

Ciccone, Antonio, and Giovanni Peri. "Long-run Substitutability Between More and Less Educated Workers: Evidence From U.S. States, 1950-1990." The Review of Economics and Statistics 87.4 (2005): 652-663. Web.

Dunleavy, James A., and Henry A. Gemery. "The Role of Migrant Stock and Lagged Migration in the Settlement Patterns of Nineteenth Century Immigrants." The 
Review of Economics and Statistics 59.2 (1977): 137-144. JSTOR. Web. 16 Aug. 2016.

Leonard, Mark. "Getting a Grip on Migration." Project Syndicate. Project Syndicate, 17 June 2016. Web. 22 Aug. 2016.

Lewis, Ethan G. Immigration, Skill Mix, and the Choice of Technique (May 2005). FRB Philadelphia Working Paper No. 05-8.

Longhi, S., P. Nijkamp, and J. Poot. "A meta-analyst assessment of the effect of immigration on wages." Journal of Economic Surveys 19:3 (2005): 451-477

Ottaviano, Gianmarco I. P., Greg C. Wright and G. Peri. "Immigration, Offshoring, and American Jobs." American Economic Review 103:5 (2013) 1925-1959

Ottaviano, Gianmarco I.P, and Giovanni Peri." Rethinking the Gains From Immigration: Theory and Evidence From the U.S." Working paper no. 11672. Cambridge, MA: National Bureau of Economic Research, 2005. Print.

Peri, Giovanni. "The effect of immigration on productivity: Evidence from U.S. states." Review of Economics and Statistics 94:1 (2009) 348-358

Peri, Giovanni. "Do immigrant workers depress the wages of native workers?" IZA World of Labor 42 (2014) 1-9.

\section{NOTES}

${ }^{1}$ Using the lagged population data causes us to lose two observations, as Alaska and Hawaii were not admitted into the union until after my first lagged observation period. 